\title{
Nesting a city input-output table in a multiregional framework: a case example with the city of Bogota
}

\author{
Fabio Monsalve ${ }^{1 *}$ (D), Mateo Ortiz ${ }^{1}$, María-Ángeles Cadarso ${ }^{1}$, Enrique Gilles ${ }^{2}$, Jorge Zafrilla ${ }^{1}$ and \\ Luis-Antonio López ${ }^{1}$
}

*Correspondence:

fabio.monsalve@uclm.es

${ }^{1}$ Global Energy

and Environmental

Economics Analysis Research Group, Faculty of Economics and Business, University of Castilla-La Mancha,

Albacete, Spain

Full list of author information is available at the end of the article

\begin{abstract}
In parallel with the increasing availability of multiregional input-output (MRIO) tables, there has been a growing concern on 10 modelling at lower levels of spatial disaggregation, to reflect the particular features of cities better. The urbanization process is one of the salient characteristics of the current stage of globalization, so it is imperative to know more about their global economic, social and environmental impacts. MRIO initiatives are defined at the country level, which means that we are potentially losing some key information about cities and their economic structures. In this paper, we fill this gap by putting together the IOT for the city of Bogota (Colombia) into the wellknown OECD's ICIO database. After describing the structure of both IOTs, we document the harmonization and nesting procedures in a step by step approach, focusing on the main challenges and assumptions that we have to make. Additionally, a case study has been carried out to weight the level of integration of Bogota in global value chains. The analysis proves the low level of global integration: the bulk of the valued-added generated in Bogota due to the city's exports comes from the economy of the rest of the country and presents a significant deficit in its value-added balance. Apart, we hope it could shed some light to conduct similar adaptations for other cities.
\end{abstract}

Keywords: Nesting, Multiregional input-output model, Cities, Bogota, IClO

\section{Introduction}

Global multiregional input-output modelling (MRIO) has blossomed in the last decades in parallel with the increasingly available data, computational power and interest among the scientific community for the adequacy of this sort of models to appropriately measure the increasing complexity of global production and consumption through global value chains. MRIO models are mainly used to assess the environmental and social pressures of the global economy (Wiedmann and Lenzen 2018). These models depict at a high-resolution level-country and sectorial - the international trade of goods and services, which allows them to provide detailed and useful information for stakeholders and policymakers (Wiedmann and Barrett 2013).

The unit of analysis of those models is usually the country. Most of the available multiregional input-output databases provide individual country information for major

(c) The Author(s) 2020 This article is licensed under a Creative Commons Attribution 4.0 International License, which permits use, sharing adaptation, distribution and reproduction in any medium or format, as long as you give appropriate credit to the original author(s) and the source, provide a link to the Creative Commons licence, and indicate if changes were made. The images or other third party material in this article are included in the article's Creative Commons licence, unless indicated otherwise in a credit line to the material. If material is not included in the article's Creative Commons licence and your intended use is not permitted by statutory regulation or exceeds the permitted use, you will need to obtain permission directly from the copyright holder. To view a copy of this licence, visit http://creativeco mmons.org/licenses/by/4.0/ 
economies, and one or several regional aggregations for the rest of the world (RoW). Subnational units are not considered. This situation has made room for the attempt to nest single regional input-output tables (SRIO) at a subnational level into the MRIO models. The goal is to improve the estimation of regional impacts by increasing the detail and accuracy of the relationships and dynamics between and within regional economies. Economic, social and environmental performance varies between regions because regions show different specializations patterns, inter-industry linkages (both within and across regions), population densities, workers skills, to cite only a few. These aspects determine the region's vulnerability or resilience to economic downturns and climate change (Thissen et al. 2018) or their position and participation in global value chains (Meng and Yamano 2017). Malik et al. (2018) also highlight the need for a better understanding of within-countries effects of inter-regional interactions. These Spatially Explicit Input-Output models (SIO), as (Sun et al. 2019) called them, are relevant in the case of environmental assessments since they connect global production and trade to local environmental impacts and local consumption (Sun et al. 2019) or urban development (Zheng et al. 2019). These initiatives could be of the most interest in those cases where the region or city are a substantive part of the national economy, and its production systems are strongly intertwined in the global economy; as it happens in the case of Bogota which accounts for more than a quarter of the Colombian economy.

Most of the times, the "nesting" literature rely on non-survey methods to first estimate the regional input-output data due to the lack of information at the subnational level, because full-scale surveys tend to be unaffordable and time-consuming. (Boero et al. 2018) review the most common non-survey approaches, pointing to its main assumptions, such as the technology and final demand preferences homogeneity between the region and the country, and limitations, related to the use of balancing methods that might compound existing previous estimation errors. (Sun et al. 2019) provide an extensive review of SIO focusing on the environmentally extended MRIO models and the disaggregation of final demand and the environmental extensions. Examples of nested MRIO tables have increased in recent years (Sun et al. 2019) and take two main spatial directions: region-based and city-based studies. An example of the first ones is Wang et al. (2015) for the provinces of the Chinese economy, Hasegawa et al. (2015) for Japanese regions and Athanassiadis et al. (2018) for Brussels capital region. Among the second ones, the studies are mainly directed to Chinese, Australian and Japanese cities: for Melbourne city (Wiedmann et al. 2016), Hebei's cities (Zheng et al. 2019), for Tokyo in the context of interregional aspects of waste (Tsukui et al. 2015) or also combinations of them: five Chinese cities and five Australian cities (Chen et al. 2016).

In the case of the city of Bogotá, the advantage is the disposal of a survey-based input-output table of Bogotá, which avoids the limitations related to the use of nonsurvey methods before the nesting procedure. This paper aims to nest the single region input-output table of the city of Bogota (Secretaria de Hacienda Distrital 2015) into the Inter-Country Input-Output (ICIO) Table provided by the Organization for Economic Co-operation and Development (OECD) (OCDE 2018). This will allow us to have a powerful tool in order to assess and unravel the complex relationships of Bogotá with the rest of the country and other countries of South America and the rest of the world, how the city is involved in global value chains and its sustainability. 


\section{Nesting Bogota's IOT into an MRIO table}

\subsection{Data requirement}

Only two free available MRIO databases include individual data for Colombia, i.e., EORA (Lenzen et al. 2013) and ICIO (OCDE 2018). The greater sectorial disaggregation (36 versus 26 ) of the latter led us to choose this dataset as the mother matrix. It consists of a time series of MRIO tables ranging from 2005 to 2015 (11 years), covering 36 harmonized industries for 64 countries-36 OECD and 28 Non-OCDE economies-and a RoW Region. It also provides two split tables for China and Mexico with processing activities (see Fig. 1).

In turn, the input-output information for the city of Bogotá is available only for 2012 (Secretaria de Hacienda Distrital 2015), and it is expressed in local currency (Colombian peso, COP). The city IOT features three agriculture sectors, two mining sectors, 21 industrial sectors, three sectors for Electricity, Gas and Water and 19 services, for a total of 48 sectors. Final demand identifies household consumption, government consumption, and spending on the gross formation of capital. Imports and exports are disaggregated into international trade and trade with the rest of the country.

It is worth noting that imports and exports are treated very differently in the SRIO and MRIO models selected in this article. Specifically, Bogota's SRIO table is the competitive-imports type (Miller and Blair 2009), so domestic production and imports are indistinctly included in intermediate and final consumption blocks; moreover, the table does not distinguish between Bogota's intermediate and final exports. This structure posits some particular problems in the nesting process.

\subsection{Data harmonization}

Since Bogota's IOT and ICIO-OECD tables have different features and structure, harmonizing both datasets is a necessary step before starting the nesting process.

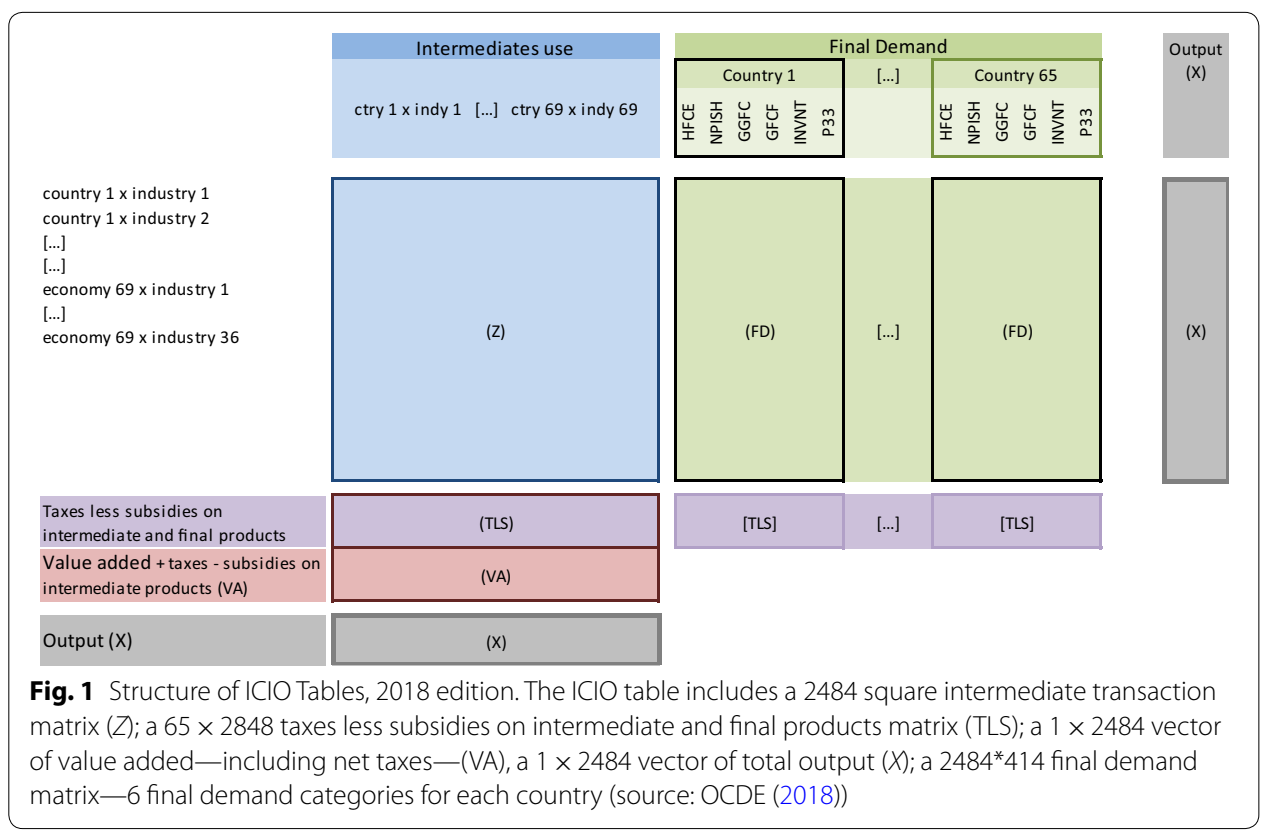


Harmonization starts by selecting 2012 as the central period of our analysis: although ICIO-OCDE latest release includes more recent years (until 2015), as said above Bogota IOT is only available for 2012, so we found ourselves forced to work with 2012 data. Afterward, we converted Bogota IOT units (originally in COP million) to USD million using the average exchange rate for 2012 ( 1 USD $=1796.9$ COP). Once we have homogenized currency and years, we applied some transformations to ICIO tables in order to simplify the nesting process.

In a first step, focusing on ICIO tables, we aggregated the information of processing exports from Mexico and China to the corresponding main entries of each country. We found this distinction not relevant given the aim of this work, which is to shed light on topics related to Bogota. The second modification made on ICIO tables was to change the placement of Colombia's data within the ICIO tables. Colombia is originally placed on 43th position in the ICIO regional arrangement (counting from left to right and from top to bottom), we re-located it on the first position for practical reasons as such relocation simplifies our calculations and the presentation of the results. Eventually, Bogota's entries will be inserted first in the nested table, and Colombia will be placed in the second position.

\subsection{Sectorial correspondences}

The final step to complete the harmonization was to find correspondences in the sectorial arrangement of ICIO and Bogota IOT and make them consistent in one sectorial classification. ICIO tables originally have 36 industries based on ISIC REV. 4 (United Nations 2008) while Bogota IOT has 48 sectors based on an adaptation of ISIC REV. 3.1 to the Colombian economy made by DANE (2009). Since differences in descriptions of activities and sectors of both classifications are significant, in order to find appropriate correspondences, we had to reduce both sets of data to a sectoral arrangement of $32 \mathrm{sec}-$ tors, following, as far as possible, the classification of the ICIO tables (mother matrix). Tables 1 and 2 depict sectorial concordances applied for each dataset:

\section{Methods}

The simplest way to undertake the process of nesting a subnational matrix-a city table in our case-into an MRIO is to split the original national set of data in the latter into two separated units. On the one hand, it means that we need to make room for Bogota (i.e., to add a set of rows and columns) in the original ICIO table, spaces that will be filled with the IO data from the city table and, on the other hand, to replace the original Colombian information with re-calculated data coming from the subtraction of Bogota data from the original Colombian ones. We will call these regions Rest of Colombia (RoC hereafter).

To proceed, we set up an augmented MRIO table, including a $Z$ matrix of intermediate consumption, another matrix for final demand denoted by $\boldsymbol{Y}$, and two row vectors of value added $(\boldsymbol{V})$ and total output $(\boldsymbol{X})$. All of their elements indexed by exporting country $r$, importing country $s$, supplying sector $i$, and demanding sector $j$. With this at hand, $Z^{r s}$ accounts for the $32 \times 32$ intermediate consumption matrix from region $\mathrm{r}$ to region $\mathrm{s} ; Y^{r s}$ is the $32 \times 1$ vector of final demand from region $\mathrm{r}$ to 
Table 1 Sectorial correspondences for ICIO tables. Source: own elaboration

\begin{tabular}{|c|c|c|c|}
\hline ICIO Code & $\mathrm{ICIO}$ industries & $\begin{array}{l}\text { Harmonized industries for nesting } \\
\text { process }\end{array}$ & Code \\
\hline D01T03 & Agriculture, forestry and fishing & Agriculture, forestry and fishing & $\mathrm{c} 1$ \\
\hline D05T06 & $\begin{array}{l}\text { Mining and extraction of energy producing } \\
\text { products }\end{array}$ & Mining and quarrying & $c 2$ \\
\hline D07T08 & $\begin{array}{l}\text { Mining and quarrying of non-energy produc- } \\
\text { ing products }\end{array}$ & & \\
\hline D09 & Mining support service activities & & \\
\hline D10T12 & Food products, beverages and tobacco & Food products, beverages and tobacco & c3 \\
\hline D13T15 & $\begin{array}{l}\text { Textiles, wearing apparel, leather and related } \\
\text { products }\end{array}$ & $\begin{array}{l}\text { Textiles, wearing apparel, leather and related } \\
\text { products }\end{array}$ & $c 4$ \\
\hline D16 & Wood and products of wood and cork & Wood and products of wood and cork & $c 5$ \\
\hline D17T18 & Paper products and printing & Paper products and printing & c6 \\
\hline D19 & Coke and refined petroleum products & Coke and refined petroleum products & c7 \\
\hline D20T21 & Chemicals and pharmaceutical products & Chemicals and pharmaceutical products & $\mathrm{c} 8$ \\
\hline D22 & Rubber and plastic products & Rubber and plastic products & c9 \\
\hline D23 & Other non-metallic mineral products & Other non-metallic mineral products & $c 10$ \\
\hline D24 & Basic metals & Basic metals & c11 \\
\hline D25 & Fabricated metal products & Fabricated metal products & $\mathrm{c} 12$ \\
\hline D26 & Computer, electronic and optical products & Computer, electronic and optical products & c13 \\
\hline D27 & Electrical equipment & Electrical equipment & c14 \\
\hline D28 & Machinery and equipment, nec & Machinery and equipment, nec & $c 15$ \\
\hline D29 & Motor vehicles, trailers and semi-trailers & Motor vehicles, trailers and semi-trailers & c16 \\
\hline D30 & Other transport equipment & Other transport equipment & c17 \\
\hline D31T33 & $\begin{array}{l}\text { Other manufacturing; repair and installation } \\
\text { of machinery and equipment }\end{array}$ & $\begin{array}{l}\text { Other manufacturing; repair and installation } \\
\text { of machinery and equipment }\end{array}$ & $\mathrm{c} 18$ \\
\hline D35T39 & $\begin{array}{l}\text { Electricity, gas, water supply, sewerage, waste } \\
\text { and remediation services }\end{array}$ & $\begin{array}{l}\text { Electricity, gas, water supply, sewerage, } \\
\text { waste and remediation services }\end{array}$ & c19 \\
\hline D41T43 & Construction & Construction & $c 20$ \\
\hline D45T47 & $\begin{array}{l}\text { Wholesale and retail trade; repair of motor } \\
\text { vehicles }\end{array}$ & $\begin{array}{l}\text { Wholesale and retail trade; repair of motor } \\
\text { vehicles }\end{array}$ & $c 21$ \\
\hline D49T53 & Transportation and storage & Transportation and storage & $c 22$ \\
\hline D55T56 & Accommodation and food services & Accommodation and food services & $c 23$ \\
\hline D58T60 & $\begin{array}{l}\text { Publishing, audiovisual and broadcasting } \\
\text { activities }\end{array}$ & $\begin{array}{l}\text { Telecommunications and other information } \\
\text { services }\end{array}$ & $c 24$ \\
\hline D61 & Telecommunications & & \\
\hline D62T63 & IT and other information services & & \\
\hline D64T66 & Financial and insurance activities & Financial and insurance activities & $\mathrm{c} 25$ \\
\hline D68 & Real estate activities & Real estate activities & $c 26$ \\
\hline D69T82 & Other business sector services & Other business sector services & $c 27$ \\
\hline D84 & $\begin{array}{l}\text { Public admin. and defence; compulsory } \\
\text { social security }\end{array}$ & $\begin{array}{l}\text { Public admin. and defence; compulsory } \\
\text { social security }\end{array}$ & $\mathrm{c} 28$ \\
\hline D85 & Education & Education & c29 \\
\hline D86T88 & Human health and social work & Human health and social work & c30 \\
\hline D90T96 & $\begin{array}{l}\text { Arts, entertainment, recreation and other } \\
\text { service activities }\end{array}$ & $\begin{array}{l}\text { Arts, entertainment, recreation and other } \\
\text { service activities }\end{array}$ & c31 \\
\hline D97T98 & Private households with employed persons & Private households with employed persons & c32 \\
\hline
\end{tabular}

region s; $V^{r}$ and $X^{r}$ represent region $r$ value added and gross output vectors, respectively, both of dimensions $1 \times 32$. We place Bogota data in the first block of rows and columns, the Rest of Colombia in the second position, and the rest of the world countries from positions 3 to 66 . Hence, the augmented intermediate matrix $Z$ accounts 
Table 2 Sectorial correspondences for Bogota IOT table. Source: own elaboration

\begin{tabular}{|c|c|c|c|}
\hline BOG code & Bogota IOT industries & $\begin{array}{l}\text { Harmonized industries for nesting } \\
\text { process }\end{array}$ & Code \\
\hline 1 & Productos agropecuarios & \multirow[t]{2}{*}{ Agriculture, forestry and fishing } & \multirow[t]{2}{*}{$\mathrm{cl}$} \\
\hline 2 & Productos de la silvicultura & & \\
\hline 3 & Productos de la pesca y la acuicultura & \multirow[t]{3}{*}{ Mining and quarrying } & \multirow[t]{3}{*}{$c 2$} \\
\hline 4 & Carbón, petróleo, gas y minerales metálicos & & \\
\hline 5 & Minerales no metálicos & & \\
\hline 6 & Productos alimenticios y bebidas & Food products, beverages and tobacco & c3 \\
\hline 7 & Productos textiles & \multirow{3}{*}{$\begin{array}{l}\text { Textiles, wearing apparel, leather and related } \\
\text { products }\end{array}$} & \multirow[t]{3}{*}{$c 4$} \\
\hline 8 & $\begin{array}{l}\text { Tejidos de punto y ganchillo; prendas de } \\
\text { vestir }\end{array}$ & & \\
\hline 9 & $\begin{array}{l}\text { Curtido y preparado de cueros, productos de } \\
\text { cuero y calzado }\end{array}$ & & \\
\hline 10 & $\begin{array}{l}\text { Productos de madera, corcho, paja y materi- } \\
\text { ales trenzables }\end{array}$ & Wood and products of wood and cork & c5 \\
\hline 11 & Productos de papel, cartón y sus productos & \multirow[t]{2}{*}{ Paper products and printing } & \multirow[t]{2}{*}{ c6 } \\
\hline 12 & Edición, impresión y artículos análogos & & \\
\hline 13 & $\begin{array}{l}\text { Productos de la refinación del petróleo y } \\
\text { combustible nuclear }\end{array}$ & Coke and refined petroleum products & c7 \\
\hline 14 & Sustancias y productos químicos & Chemicals and pharmaceutical products & c8 \\
\hline 15 & Productos de caucho y de plástico & Rubber and plastic products & c9 \\
\hline 16 & Productos minerales no metálicos & Other non-metallic mineral products & $\mathrm{c} 10$ \\
\hline 17 & Productos metalúrgicos básicos & Basic metals & $\mathrm{c} 11$ \\
\hline 18 & $\begin{array}{l}\text { Productos elaborados de metal (excepto } \\
\text { maquinaria y equipo) }\end{array}$ & Fabricated metal products & $\mathrm{c} 12$ \\
\hline 20 & $\begin{array}{l}\text { Maquinaria de oficina, contabilidad e } \\
\text { informática }\end{array}$ & \multirow[t]{3}{*}{ Computer, electronic and optical products } & \multirow[t]{3}{*}{$\mathrm{c} 13$} \\
\hline 22 & $\begin{array}{l}\text { Equipo y aparatos de radio, televisión y } \\
\text { comunicaciones }\end{array}$ & & \\
\hline 23 & $\begin{array}{l}\text { Instrumentos médicos, ópticos y de pre- } \\
\text { cisión, fabricación de relojes }\end{array}$ & & \\
\hline 21 & Maquinaria y aparatos eléctricos ncp & Electrical equipment & c14 \\
\hline 19 & Maquinaria y equipo & Machinery and equipment, nec & c15 \\
\hline 24 & $\begin{array}{l}\text { Vehículos automotores, remolques y semir- } \\
\text { remolques }\end{array}$ & Motor vehicles, trailers and semi-trailers & c16 \\
\hline 25 & Otros tipos de equipos de transporte & Other transport equipment & $\mathrm{c} 17$ \\
\hline 26 & $\begin{array}{l}\text { Muebles; industrias manufactureras ncp; } \\
\text { reciclaje }\end{array}$ & $\begin{array}{l}\text { Other manufacturing; repair and installation } \\
\text { of machinery and equipment }\end{array}$ & $\mathrm{c} 18$ \\
\hline 27 & Energía eléctrica & \multirow{4}{*}{$\begin{array}{l}\text { Electricity, gas, water supply, sewerage, waste } \\
\text { and remediation services }\end{array}$} & \multirow[t]{4}{*}{ c19 } \\
\hline 28 & Gas domiciliario & & \\
\hline 29 & Agua & & \\
\hline 30 & $\begin{array}{l}\text { Servicios de alcantarillado y eliminación de } \\
\text { desperdicios, saneamiento y otros servicios } \\
\text { de protección del medio ambiente }\end{array}$ & & \\
\hline 31 & $\begin{array}{l}\text { Trabajos de construcción de edificaciones; } \\
\text { acondicionamiento de edificaciones }\end{array}$ & \multirow[t]{2}{*}{ Construction } & \multirow[t]{2}{*}{$\mathrm{c} 20$} \\
\hline 32 & $\begin{array}{l}\text { Trabajos de construcción de obras de ing- } \\
\text { eniería civil }\end{array}$ & & \\
\hline 33 & Comercio & \multirow{2}{*}{$\begin{array}{l}\text { Wholesale and retail trade; repair of motor } \\
\text { vehicles }\end{array}$} & \multirow[t]{2}{*}{ c21 } \\
\hline 34 & $\begin{array}{l}\text { Servicios de reparación de automotores, de } \\
\text { artículos personales y domésticos }\end{array}$ & & \\
\hline 36 & Servicios de transporte terrestre & \multirow[t]{3}{*}{ Transportation and storage } & \multirow[t]{3}{*}{$c 22$} \\
\hline 37 & Servicios de transporte por vía aérea & & \\
\hline 38 & $\begin{array}{l}\text { Servicios complementarios y auxiliares al } \\
\text { transporte }\end{array}$ & & \\
\hline
\end{tabular}


Table 2 (continued)

\begin{tabular}{|c|c|c|c|}
\hline BOG code & Bogota IOT industries & $\begin{array}{l}\text { Harmonized industries for nesting } \\
\text { process }\end{array}$ & Code \\
\hline 35 & $\begin{array}{l}\text { Servicios de alojamiento, suministro de } \\
\text { comidas y bebidasv }\end{array}$ & Accomodation and food services & $c 23$ \\
\hline 39 & Servicios de correos y telecomunicaciones & $\begin{array}{l}\text { Telecommunications and other information } \\
\text { services }\end{array}$ & $c 24$ \\
\hline 40 & $\begin{array}{l}\text { Servicios de intermediación financiera, de } \\
\text { seguros y servicios conexos }\end{array}$ & Financial and insurance activities & $\mathrm{c} 25$ \\
\hline 41 & $\begin{array}{l}\text { Servicios inmobiliarios y de alquiler de } \\
\text { vivienda }\end{array}$ & Real estate activities & $c 26$ \\
\hline 42 & $\begin{array}{l}\text { Servicios a las empresas excepto servicios } \\
\text { financieros e inmobiliarios }\end{array}$ & Other business sector services & $c 27$ \\
\hline 43 & $\begin{array}{l}\text { Administración pública y defensa; dirección, } \\
\text { administración y control del sistema de } \\
\text { seguridadsocial }\end{array}$ & $\begin{array}{l}\text { Public admin. and defence; compulsory } \\
\text { social security }\end{array}$ & $\mathrm{c} 28$ \\
\hline 44 & Servicios de enseñanza de mercado & Education & c29 \\
\hline 45 & Servicios de enseñanza de no mercado & & \\
\hline 46 & Servicios sociales y de salud de mercado & Human health and social work & c30 \\
\hline 47 & $\begin{array}{l}\text { Servicios de asociaciones y esparcimiento, } \\
\text { culturales, deportivos y otros servicios de } \\
\text { mercado }\end{array}$ & $\begin{array}{l}\text { Arts, entertainment, recreation and other } \\
\text { service activities }\end{array}$ & c31 \\
\hline 48 & Servicios domésticos & Private households with employed persons & c32 \\
\hline
\end{tabular}

for 66 countries or regions ( 65 from the original ICIO plus the city of Bogota) and 32 sectors. Figure 2 shows the general structure of the augmented MRIO table, where the information in the green areas needs to be calculated. Recall Bogota is region 1, and that $\mathrm{RoC}$ is region 2 .

The task ahead is about filling the green areas of Fig. 2, corresponding to intermediate and final consumption as well as the value added and total output vectors, with the information of Bogota's SRIO and ICIO's MRIO. The blank areas are those of the rest of the world countries, which remain unchanged with respect to the original ICIO. In what follows, we first address the treatment of re-exports, to then undertake these tasks in the subsequent sections.

\subsection{Dealing with re-exports (imported goods eventually exported)}

A competitive input-output table includes the re-exported, i.e., those imported goods that are re-exported to the rest of the regions of the country, or even, to rest of the world without further processing. In the specific case of Bogota, this could be particularly intense in some sectors such as "Agriculture, Forestry and Fishing" or "Computer, electronic and optical products" for they show a high volume of total supply, but a low local production, $2 \%$, and $4 \%$, respectively. To deal with this accounting issue, we first identify if there are re-exports in the sectors by comparing the imports in each sector with the total output (Zheng et al. 2019). If imports were larger than local output, we would assume the existence of re-exports. Otherwise, there will be zero. In equivalent terms, re-exports will be calculated using the following equation:

$$
\mathrm{RX}_{i}^{\mathrm{B}}=\left\{\begin{array}{ll}
M_{i}^{\mathrm{RoC}}+M_{i}^{\mathrm{RoW}}-Z_{i}^{\mathrm{B}}-A_{i}^{\mathrm{B}}, & \mathrm{RX}_{i}^{\mathrm{B}}>0 \\
0 & \text { otherwise }
\end{array},\right.
$$




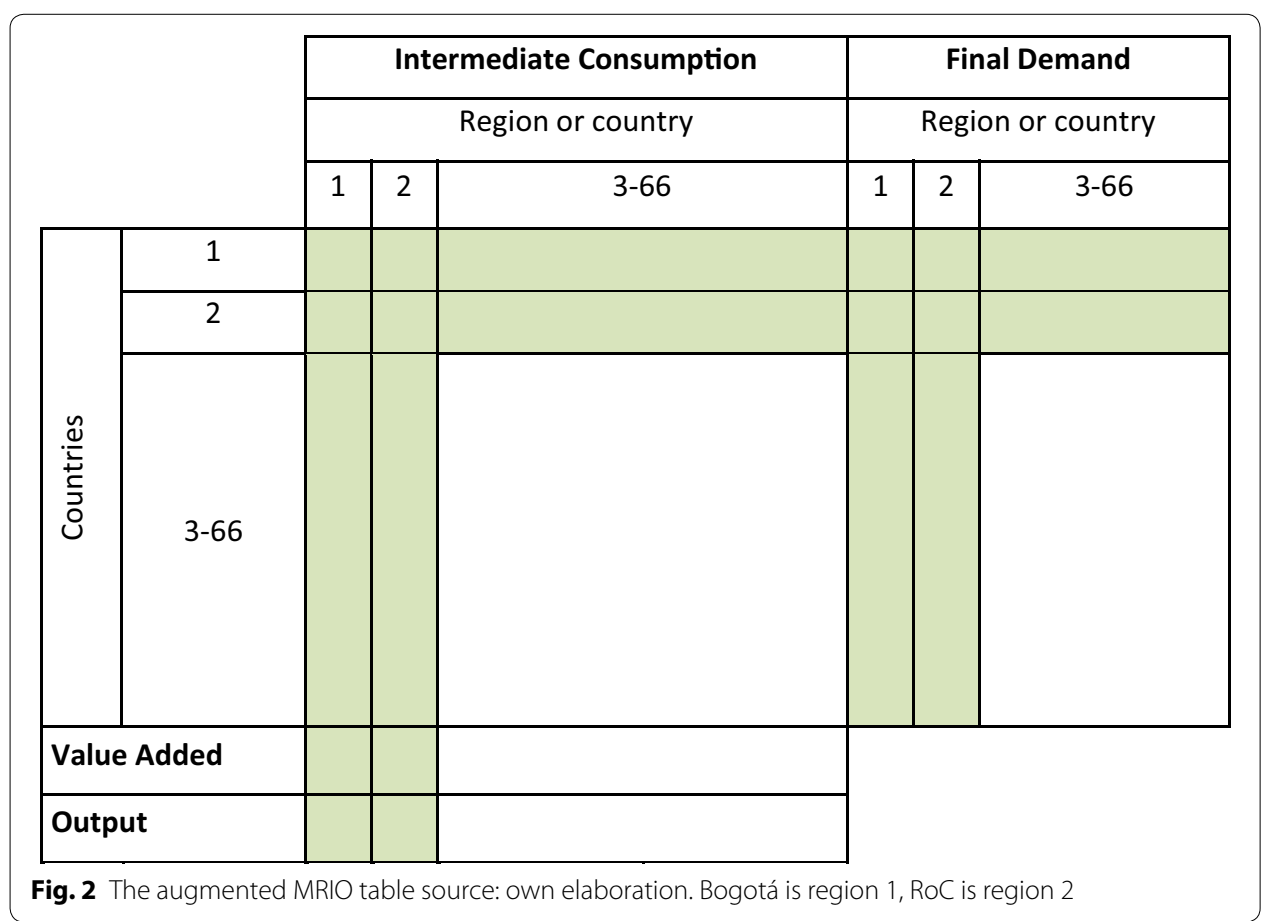

where $\mathrm{RX}_{i}^{\mathrm{B}}$ are sector $i$ re-exports of the city of Bogota; $M_{i}^{\mathrm{RoC}}$ and $M_{i}^{\mathrm{RoW}}$ the city imports of sector $i$ from the Rest of Colombia ( $\mathrm{RoC}$ ) and the rest of the world (RoW), respectively; $Z_{i}^{B}$ the intermediate consumption of sector $i$; and $A_{i}^{B}$ denotes sector $i$ domestic absorption of the city of Bogota, which includes total final consumption (by households and the government) and fixed capital formation.

Once the presence of re-exports is detected, they will be proportionally subtracted from sectorial imports, as well as exports, in a way that takes into account the share of regional and international imports. To do that, we first define the share of imports from the Rest of the World as

$$
r_{i}^{\mathrm{m}}=\frac{M_{i}^{\mathrm{RoW}}}{M_{i}^{\mathrm{RoC}}+M_{i}^{\mathrm{RoW}}} .
$$

Then, we apply Eq. (2) to find the corrected imports from each region, using the following two equations:

$$
\begin{aligned}
& \bar{M}_{i}^{\text {RoW }}=M_{i}^{R o W}-r_{i}^{m} R X_{i}^{B} \\
& \bar{M}_{i}^{\mathrm{RoC}}=M_{i}^{\mathrm{RoC}}-\left(1-r_{i}^{\mathrm{m}}\right) \mathrm{RX}_{i}^{\mathrm{B}},
\end{aligned}
$$

where $\bar{M}_{i}^{\mathrm{RoW}}$ and $\bar{M}_{i}^{\mathrm{RoC}}$ are the imports net of "re-exports" from RoW and RoC, respectively. We proceed in a similar way to subtract re-exports from exports according to the following equations: 


$$
\begin{aligned}
& r_{i}^{\mathrm{x}}=\frac{X_{i}^{\mathrm{RoW}}}{X_{i}^{\mathrm{RoC}}+X_{i}^{\mathrm{RoW}}}, \\
& \bar{X}_{i}^{\mathrm{RoW}}=X_{i}^{\mathrm{RoW}}-r_{i}^{x} \mathrm{RX}_{i}^{\mathrm{B}}, \\
& \overline{\mathrm{X}}_{\mathrm{i}}^{\mathrm{RoC}}=\mathrm{X}_{\mathrm{i}}^{\mathrm{RoC}}-\left(1-\mathrm{r}_{\mathrm{i}}^{\mathrm{x}}\right) \mathrm{R}_{\mathrm{i}}^{\mathrm{B}},
\end{aligned}
$$

where $\bar{X}_{i}^{\mathrm{RoW}}$ and $\bar{X}_{i}^{\mathrm{RoC}}$ are net exports of "re-exports" from RoW and RoC, respectively.

Results on corrected imports are presented in Table 3.

Figure 3 provides a more detailed focus on our augmented MRIO, identifying some key parts that will be addressed in the next pages.

\subsection{Extraction of domestic and imported information}

A competitive table such as Bogota's SRIO does not distinguish between domestically produced and imported products, i.e., imports are included in both intermediate and final consumption. In this subsection we deal with this issue, applying a procedure that will allow us to identify intermediate imports (areas [4] and [7] in Fig. 3) and final imports (areas [12] and [15] in Fig. 3), in both cases distinguishing between the Rest of Colombia and other countries sources. Once those components are identified, local results are going to be obtained by differences (areas [1] and [9]).

To do that, and absent further information, we assume that the distribution of geographical origins of goods and services is the same for both intermediate and final uses (Weber et al. 2008; Meng et al. 2016; Zheng et al. 2019). In other words, for any given product used in the city, there is a fixed share of origins (local, regional and from third countries) that applies for both intermediate and final uses. Following Weber et al. (2008), we calculate the share of imports from a given country or region $r$ on the total (net) supply of good and services as

$$
s_{i}^{r}=\frac{\bar{M}_{i}^{r}}{Q_{i}+\bar{M}_{i}-\bar{X}_{i}}, \quad r \in\{2, \ldots, 66\}, \quad i \in\{1, \ldots, 32\} .
$$

Putting these shares together for each region $r$ in a $32 \times 1$ vector, we calculate the new bi-regional matrices as

$$
\begin{aligned}
& Z^{r 1}=s^{r} Z^{B}, \quad r \in\{2, \ldots, 66\}, \\
& Z^{11}=\left(\iota-\sum_{r} s^{r}\right) Z^{B}, \quad r \in\{2, \ldots, 66\},
\end{aligned}
$$

where $Z^{B}$ is the original SRIO for Bogota, which, as said before, includes domestic and imported information, and $Z^{r 1}$ are the intermediate consumption matrices from each of the $r$ regions to Bogota (region 1) in the augmented MRIO table (i.e., areas [4] and [7] of Fig. 3). In Eq. (10), $\iota$ is the unitary vector, and it is straightforward to see the intermediate consumption matrix for Bogota in the augmented MRIO $\left(Z^{11}\right)$ is obtained as a residual. 


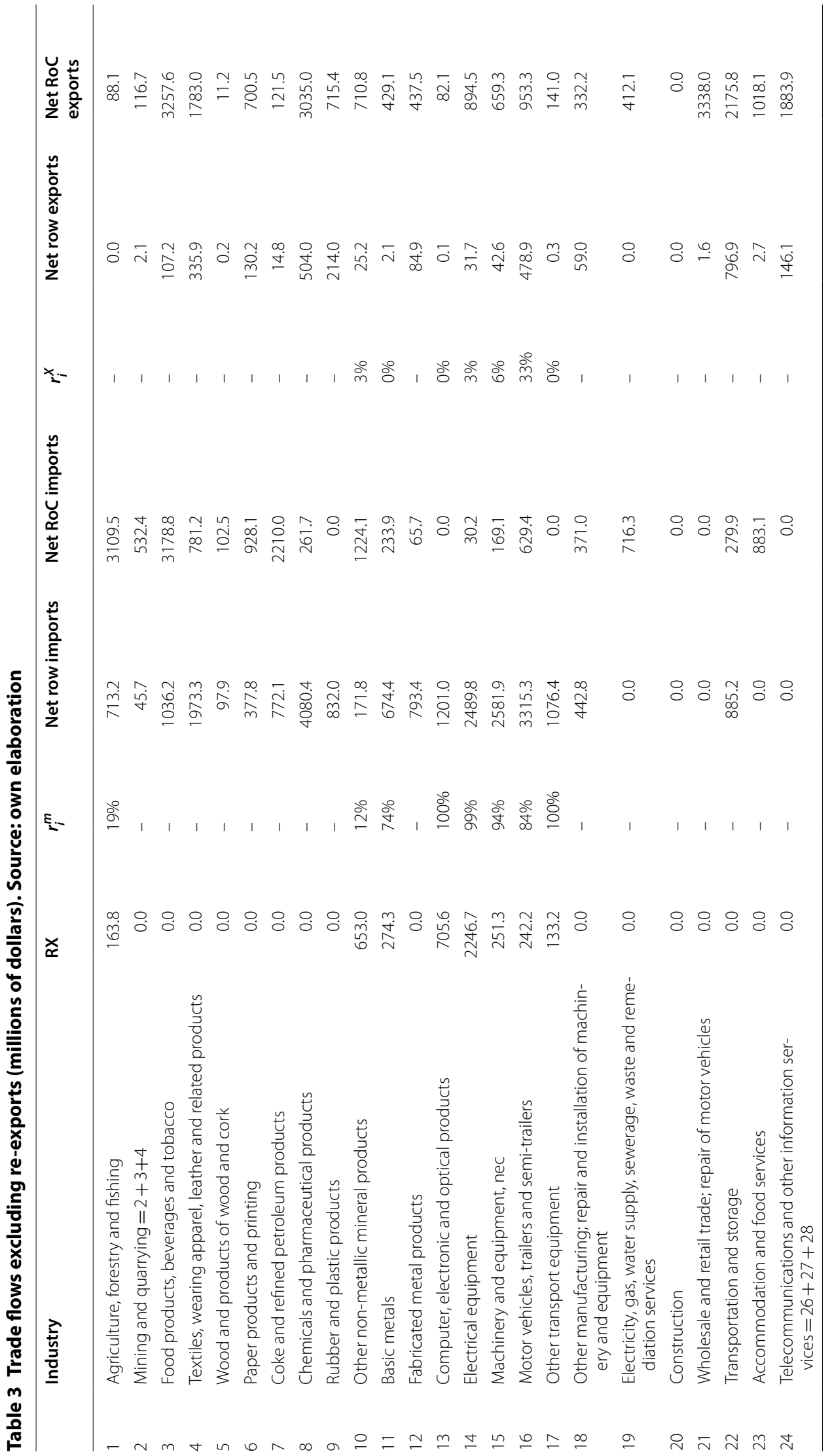




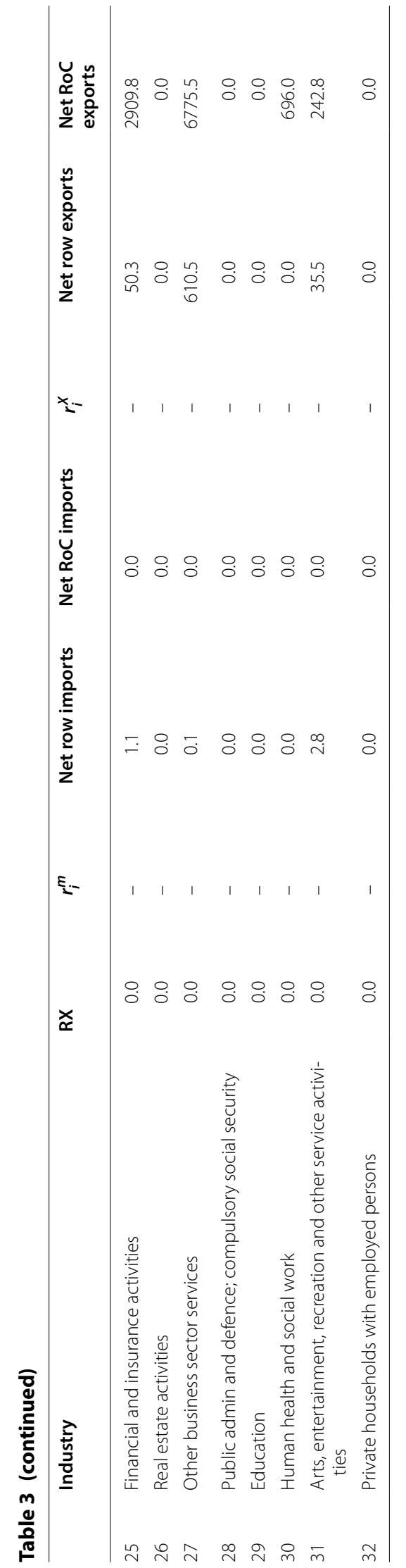




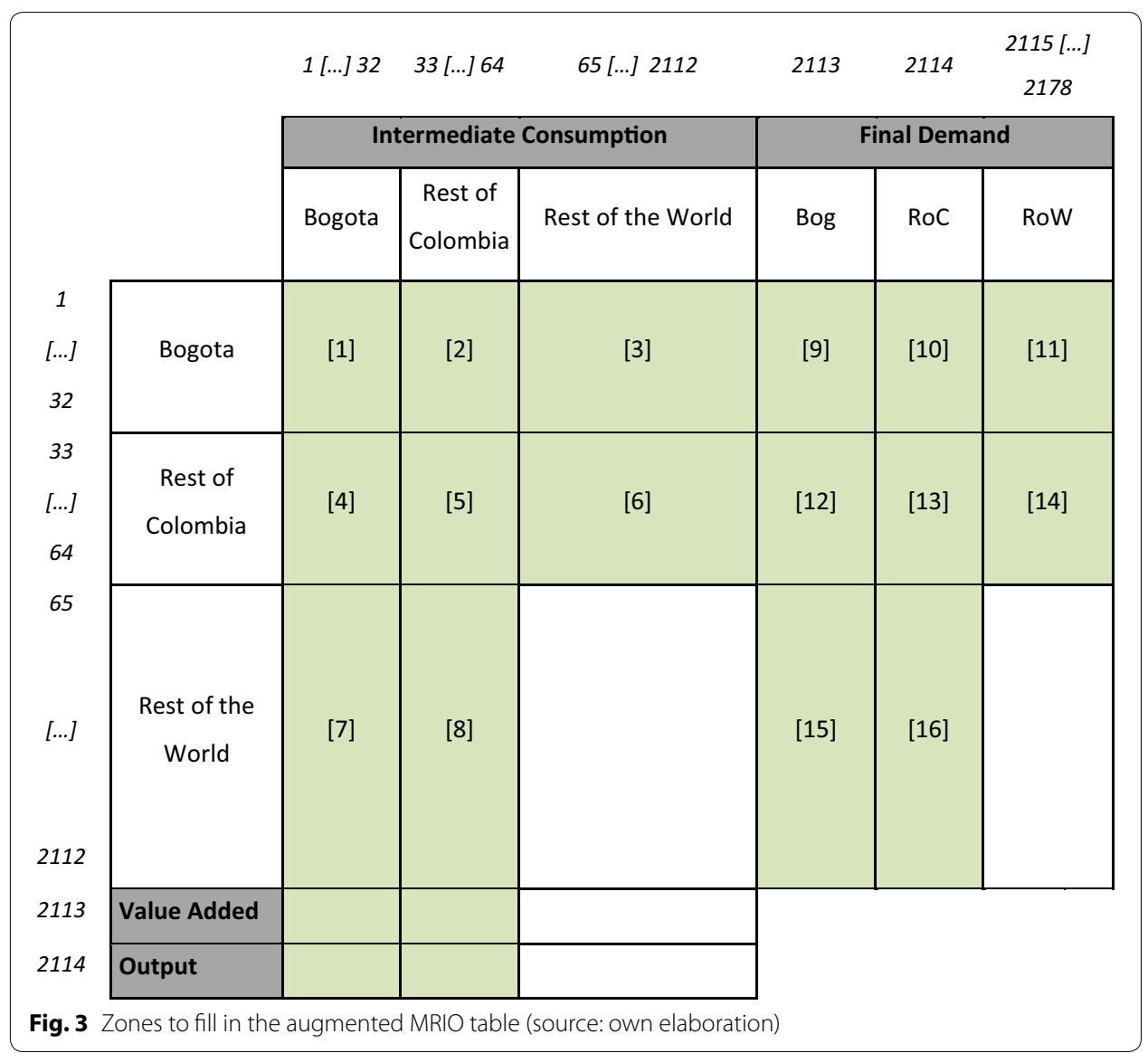

As mentioned above, we use the same approach to separate the original SRIO's final demand vector, $Y_{i}^{\mathrm{B}}$ into 66 vectors of the final demand the city faces. We apply the same coefficients of Eqs. 8-10 to compute the city's final demand vectors by replacing $Z^{B}$ by the original SRIO's $Y^{B}$ vector. With that, we fill the areas [9], [12] and [15] in Fig. 3.

\section{Processing intermediate and final exports of Bogota}

The competitive SRIO table of Bogota provides information about the regional exports, i.e., to the rest of the country and exports to the rest of the world, but without differentiation between intermediate and final. To fill this gap, we need to incorporate additional exogenous information. In our case, this information is provided by the National Administrative Department of Statistics of Colombia (DANE), which offers import and export microdata information for the city of Bogota, from which we identify final and intermediate imports and exports for 18 sectors belonging to Agriculture, Mining and Industry (DANE 2019). The information for the rest of the sectors (Electricity, Gas, Water, Construction and Services) is extracted from the Colombian data in ICIO (see Table 4).

Once the shares of Bogota's intermediate and final exports are calculated, we proceed to allocate them among destinations. We start with intermediate exports to RoC (submatrix [2] in Fig. 3), to do that we assume that the city of Bogota's exports follows the 
Table 4 Shares of intermediate and final exports and imports. Source: authors calculations based on DANE (2009) and ICIO (OCDE 2018)

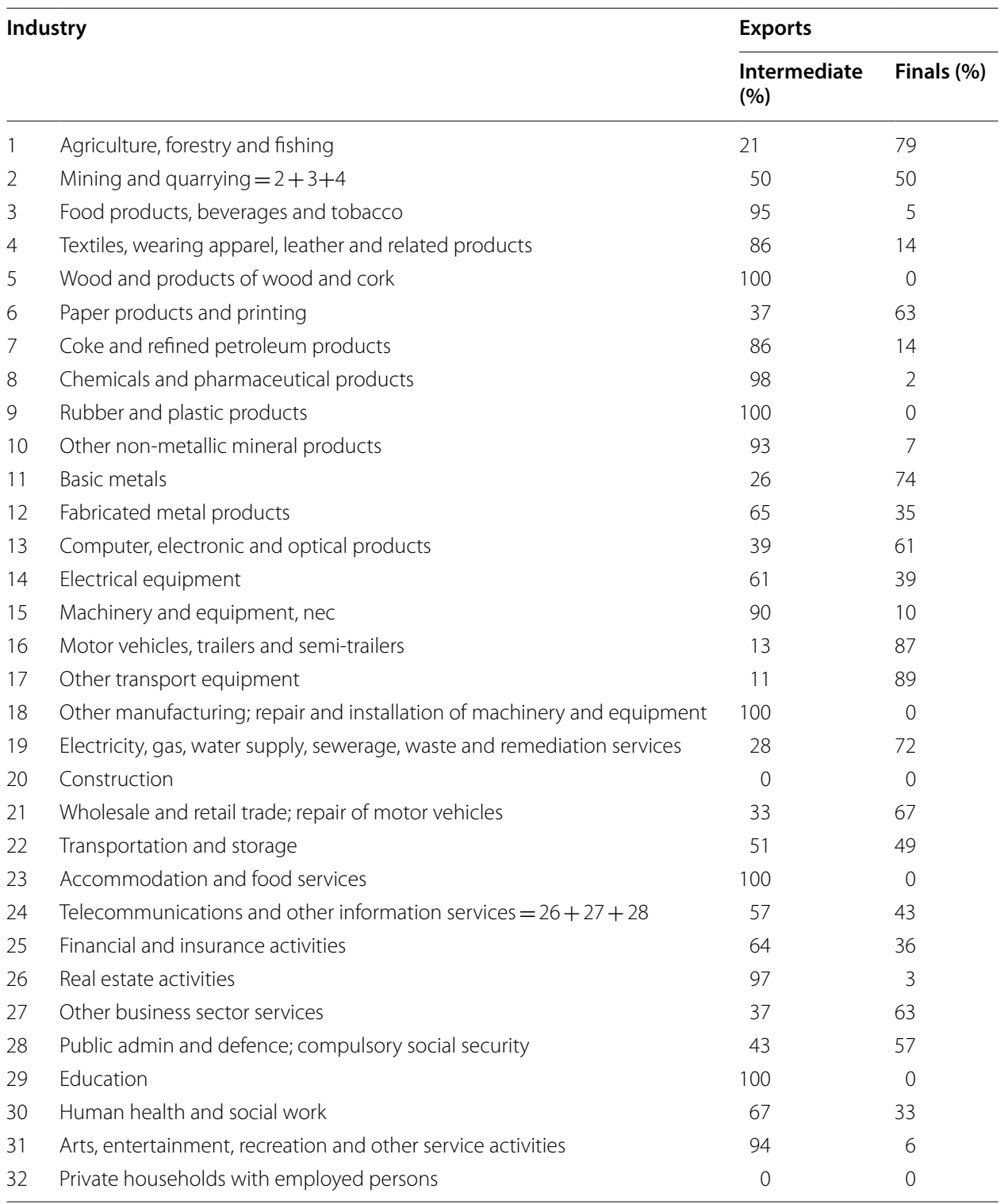

same sectorial pattern as the intermediate consumption of the original SRIO table. For the exports to the rest of the world (submatrix [3] in Fig. 3), we take a different avenue by assuming that the city of Bogota behaves as Colombia in the original ICIO MRIO table.

In what concerns final exports, we first apply the distribution of regional to total exports to the calculated final exports to identify exports to the Rest of Colombia (area [10] of Fig. 3). Then we apply the distribution of destinations obtained from ICIO to calculate final exports to each of the represented countries of the world (area [11] of Fig. 3). This ends the adjustments required to nest the Bogota information into our augmented ICIO model. 


\section{Dealing with the Rest of Colombia data}

When adding a sub-region within an existing MRIO framework, it is necessary to somehow subtract the sub-region data from the aggregated one, i.e., the city of Bogota from Colombia in this paper. The simplest way to address that is by "reversing" the usual aggregation process, i.e., completing the added rows and columns with city data and then replacing the original spaces of the whole country with those of the rest of the country, calculated by subtracting the city figures to the original country ones, in the adequate sectoral and country position. This method could, nevertheless, result in negative elements, particularly in those sectors in which the city highly contributes to the total output of the national sector.

In order to overcome those issues, we choose an alternative option: We use the technical structure of Colombia in the original ICIO table as a proxy for the technical structure of $\mathrm{RoC}$ in the new, augmented matrix. Thus, by multiplying the output of $\mathrm{RoC}$ to the corresponding technical coefficients of ICIO for Colombia, we can fill the domestic RoC matrix and the intermediate imports of RoC from the rest of the world (areas [5] and [8], respectively, in Fig. 3). Mathematically, it could be expressed as follows:

$$
\overline{z_{i j}^{r 2}}=a_{i j}^{r 2} q_{j}^{2}, \quad r \in\{2, \ldots, 66\}, \quad i, j \in\{1, \ldots, 32\},
$$

where $\overline{z_{i j}^{r 2}}$ are region 2 (i.e., RoC) imported intermediate consumptions from region $r, q_{j}^{2}$ is sector $j$ 's output of $\mathrm{RoC}$ (computed as the difference between the total output provided by ICIO and the output of the city of Bogota) and $a_{i j}^{r 2}$ represent the technical coefficients of Colombia from the original ICIO data.

The intermediate exports of $\mathrm{RoC}$ to RoW (section [6] in Fig. 3) have been addressed differently. To fill this block, we have assumed that the distribution of destinations of $\mathrm{RoC}$ is the same as Colombia's in the original ICIO, that is

$$
c_{i j}^{2 s}=\frac{z_{i j}^{\mathrm{COL}, s}}{\sum_{s} z_{i j}^{\mathrm{COLs}}}, \quad \forall s, \forall i, \forall j,
$$

where $c_{i j}^{2 s}$ are the coefficients of distribution and $z_{i j}^{\mathrm{COL}, s}$ the intermediate consumption of Colombia in the original ICIO matrix. Therefore, the intermediate exports of RoC to RoW will be obtained by applying the following equation:

$$
\overline{z_{i j}^{2 s}}=c_{i j}^{2 s} q_{j}^{2}, \quad s \in\{3, \ldots, 66\}, \quad i, j \in\{1, \ldots, 32\} .
$$

Finally, final demand data for the Rest of Colombia have been computed by differences (areas [13], [14] and [16]).

\subsection{Balancing the matrix}

To balance the matrix, we use a GRAS method (Junius and Oosterhaven 2003; Temurshoev et al. 2013) using as restriction a vector composed by the output of Bogota, in the first position, the output of the $\mathrm{RoC}$ - the difference between the output of Bogota and Colombia-in the second position, and the output of ICIO original table for the rest of countries/regions 


\section{A case study: the role of Bogota and Colombia in global value chains}

Nesting Bogota's IOT into an MRIO model allows us to analyze the city participation in global value chains, in this particular case study we will focus on value added. The relevance of that participation stems from the fact that the economic and social benefits of international trade for a country, region or city depends not only on trade volumes but also on its ability to generate value added within the territory.

A first conclusion we reach by analyzing the value added associated to global production chains is that this is more important in small regions compared to larger ones (Table 5). Indeed, while for Bogota and the Rest of Colombia the value added in exports represents, respectively, $29 \%$ and $26 \%$ of total domestic value added, the average for the five regions of the world represented in the same table is just about 13\% (similar results are obtained for imports). The size of the economy is important given that the smaller the production of a given city or region, the smaller the possibilities of enjoying scale economies and the smaller the likelihood of having natural resources, implying a larger need of trading with other partners, both domestically or internationally.

The value-added balance informs about the difference between the value added generated in exports and those generated in imports for a given region. The city of Bogota has a negative balance that reaches -5557 million dollars, a large value that represents a $21 \%$ of the value added in exports of the city. It is also high compared to the Rest of Colombia ( $\mathrm{RoC}$ ), that features a balance of -2648 million dollars, equivalent to $4 \%$ of its total value added in exports of that region (Table 5).

The flows of the city's value added in exports and imports are very dependent on the trade with the rest of the country (Fig. 4): Practically $87 \%$ of the value added generated in Bogota due to the city's exports comes from the economy of the Rest of Colombia (RoC), followed by NAFTA with a 5\% share and the Rest of the World (RoW) with 4\%. This contrasts with the RoC, where given the different composition of its exports with respect to Bogota, the main sources of value added in exports are NAFTA (37\%), followed by the RoW (21\%), while Bogota is in the third place with $17 \%$.

However, turning to the analysis of value added in imports, we verify that both Bogota and the Rest of Colombia have similar patterns (Fig. 4). While a 37\% of Bogota's value added in imports is generated in the RoC, a 32\% of RoC's value added in imports is created in Bogota. After RoC, the places where more value added

Table 5 Domestic value added, value added in trade and balance of value added, millions of US dollars, 2012

\begin{tabular}{|c|c|c|c|c|c|c|c|c|}
\hline & Domestic & & Exports (\%) & & Imports & & VA balance & $\begin{array}{l}\% \\
\text { Balance/ } \\
\text { exports }\end{array}$ \\
\hline $\mathrm{BOG}$ & 64,675 & $71 \%$ & 25,939 & $29 \%$ & 31,496 & $33 \%$ & -5557 & $-21 \%$ \\
\hline RoC & 190,088 & $74 \%$ & 68,053 & $26 \%$ & 70,701 & $27 \%$ & -2648 & $-4 \%$ \\
\hline RoSA & 2844,893 & $87 \%$ & 414,507 & $13 \%$ & 450,679 & $14 \%$ & $-36,172$ & $-9 \%$ \\
\hline NAFTA & $17,112,617$ & $92 \%$ & 1550,282 & $8 \%$ & 2154,168 & $11 \%$ & $-603,886$ & $-39 \%$ \\
\hline EU & $13,889,825$ & $86 \%$ & 2351,109 & $14 \%$ & 2051,893 & $13 \%$ & 299,216 & $13 \%$ \\
\hline $\mathrm{CHN}$ & 6507,256 & $81 \%$ & 1531,727 & $19 \%$ & 1350,410 & $17 \%$ & 181,317 & $12 \%$ \\
\hline RoW & $21,998,412$ & $87 \%$ & 3404,988 & $13 \%$ & 3237,258 & $13 \%$ & 167,729 & $5 \%$ \\
\hline Total & $62,607,766$ & $87 \%$ & 9346,606 & $13 \%$ & 9346,606 & $13 \%$ & & \\
\hline
\end{tabular}




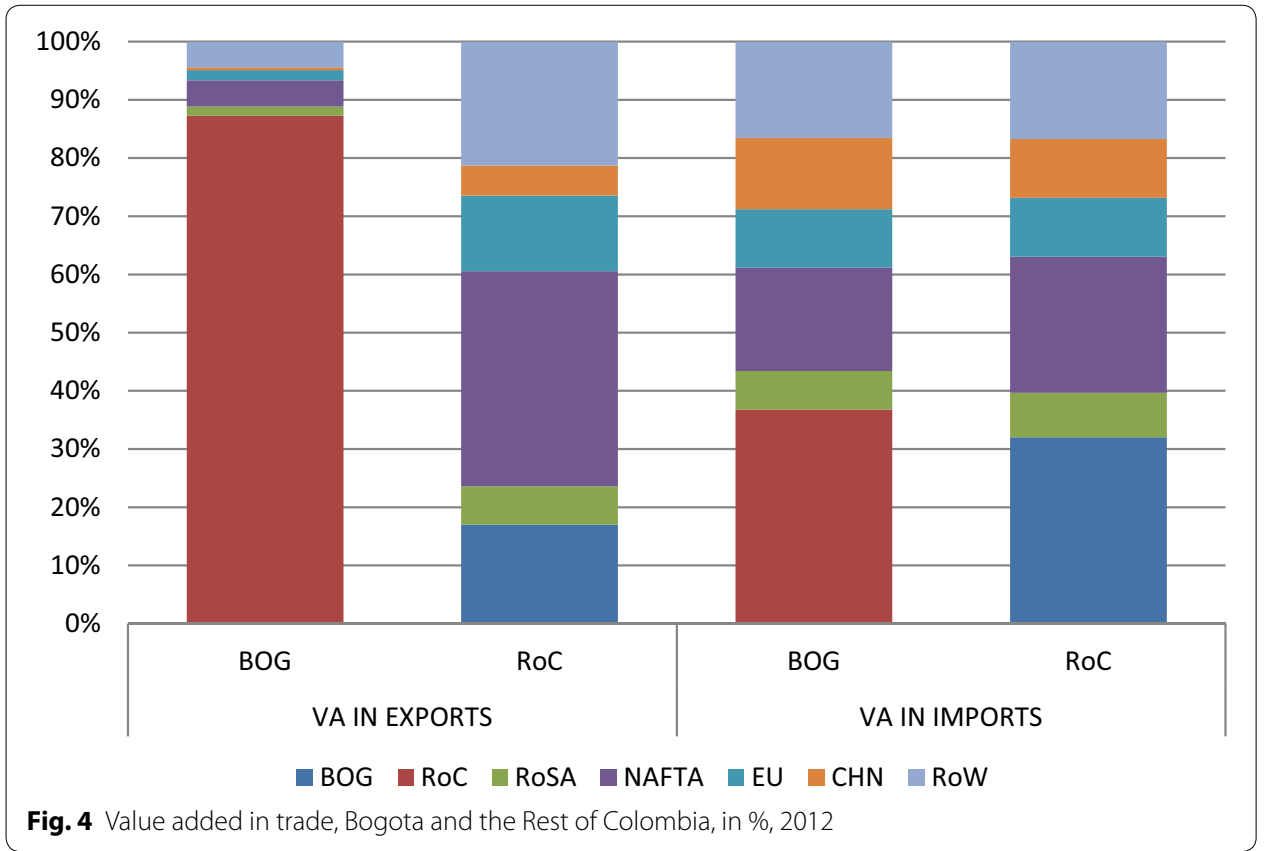

is generated by the imports of Bogota are NAFTA, RoW, China and the European Union. In both cases, the Rest of South America (RoSA) occupies the last place. This is just another way to highlight the low level of integration of Latin American countries, a well-known feature already mentioned in the literature (Torres and Gilles 2013; Banacloche et al. 2020; Gilles 2018). Overall, the evidence for the case of Bogota shows the high significance of both exports to and imports from the Rest of Colombia, relative to foreign countries.

In order to identify the role of Bogota in global value chains, we next focus on international trade, i.e. we do not take into account trade to the Rest of Colombia. It should be clear from Fig. 4 that these economic relationships with the world are small in absolute terms, particularly in what concerns to exports. See Table 6 for a complete overview of these results.

In relation to the sectors of the economy of Bogotá that participate in global value chains, first measured by their generation of value added in exports, it should be noted that they constitute a very narrow set, as it can be seen in panel (a) of Fig. 5. Indeed, three sectors belonging to the services already account for $54 \%$ of the total value added generated by exports: other business sector (31\%), transportation $(12 \%)$ and wholesale and retail trade (11\%). The list follows with the chemical industry (7\%), financial and insurance $(6 \%)$ and telecommunications and real estate activities, each one with a $5 \%$ share. The importance of the services of Bogotá in generating value added, compared to industrial sectors, shows the high specialization level of the city of Bogotá in the former.

Turning now to the analysis of the value added included in imports, the city industries that contributes the most to its generation are motor vehicles (12\%), machine and equipment (10\%), electrical equipment (9\%), construction (8\%) and food and beverage products ( $8 \%$ ). The comparison between results presented in panel (a) and (b) allows us 
Table 6 Value added in exports and imports. Bogotá, millions of US dollars, 2012

\begin{tabular}{|c|c|c|c|c|c|c|c|}
\hline \multirow[t]{2}{*}{ Bogota industries } & \multirow[t]{2}{*}{ Code } & \multicolumn{3}{|c|}{ Value added in exports } & \multicolumn{3}{|c|}{ Value added in imports } \\
\hline & & Rest of Colombia & World & Total VAiX & Rest of Colombia & World & Total VAiM \\
\hline $\begin{array}{l}\text { Agriculture, forestry } \\
\text { and fishing }\end{array}$ & $\mathrm{c} 01$ & 64 & 6 & 70 & 1141 & 361 & 1503 \\
\hline $\begin{array}{l}\text { Mining and quar- } \\
\text { rying }\end{array}$ & $\mathrm{c02}$ & 115 & 10 & 126 & - & - & - \\
\hline $\begin{array}{l}\text { Food products, } \\
\text { beverages and } \\
\text { tobacco }\end{array}$ & $\mathrm{c03}$ & 877 & 34 & 910 & 2822 & 1501 & 4323 \\
\hline $\begin{array}{l}\text { Textiles, wearing } \\
\text { apparel, leather } \\
\text { and related prod- } \\
\text { ucts }\end{array}$ & $\mathrm{c04}$ & 693 & 133 & 826 & 504 & 1444 & 1948 \\
\hline $\begin{array}{l}\text { Wood and products } \\
\text { of wood and cork }\end{array}$ & c05 & 9 & 1 & 10 & 3 & 4 & 8 \\
\hline $\begin{array}{l}\text { Paper products and } \\
\text { printing }\end{array}$ & c06 & 251 & 76 & 327 & 213 & 155 & 368 \\
\hline $\begin{array}{l}\text { Coke and refined } \\
\text { petroleum prod- } \\
\text { ucts }\end{array}$ & $\mathrm{c07}$ & 54 & 13 & 67 & 672 & 427 & 1099 \\
\hline $\begin{array}{l}\text { Chemicals and } \\
\text { pharmaceutical } \\
\text { products }\end{array}$ & $\mathrm{c08}$ & 1440 & 236 & 1676 & 76 & 1167 & 1242 \\
\hline $\begin{array}{l}\text { Rubber and plastic } \\
\text { products }\end{array}$ & c09 & 251 & 64 & 315 & 7 & 168 & 175 \\
\hline $\begin{array}{l}\text { Other non-metallic } \\
\text { mineral products }\end{array}$ & c10 & 252 & 13 & 264 & 22 & 6 & 28 \\
\hline Basic metals & $\mathrm{c} 11$ & 173 & 25 & 198 & - & - & - \\
\hline $\begin{array}{l}\text { Fabricated metal } \\
\text { products }\end{array}$ & $\mathrm{C} 12$ & 176 & 43 & 218 & 33 & 293 & 326 \\
\hline $\begin{array}{l}\text { Computer, electronic } \\
\text { and optical prod- } \\
\text { ucts }\end{array}$ & $\mathrm{c} 13$ & 14 & 1 & 15 & 0 & 730 & 731 \\
\hline Electrical equipment & c14 & 488 & 43 & 531 & 17 & 1790 & 1807 \\
\hline $\begin{array}{l}\text { Machinery and } \\
\text { equipment, nec }\end{array}$ & c15 & 236 & 18 & 254 & 124 & 2065 & 2189 \\
\hline $\begin{array}{l}\text { Motor vehicles, } \\
\text { trailers and semi- } \\
\text { trailers }\end{array}$ & c16 & 174 & 90 & 264 & 215 & 2352 & 2567 \\
\hline $\begin{array}{l}\text { Other transport } \\
\text { equipment }\end{array}$ & C17 & 23 & 3 & 26 & 1 & 1011 & 1012 \\
\hline Other manufacturing & $\mathrm{c} 18$ & 181 & 32 & 214 & 314 & 482 & 797 \\
\hline $\begin{array}{l}\text { Electricity, gas, water } \\
\text { supply }\end{array}$ & c19 & 538 & 62 & 600 & 437 & 76 & 512 \\
\hline Construction & $c 20$ & 57 & 8 & 65 & 1287 & 1656 & 2943 \\
\hline $\begin{array}{l}\text { Wholesale and retail } \\
\text { trade; repair of } \\
\text { motor vehicles }\end{array}$ & $\mathrm{c} 21$ & 2591 & 357 & 2949 & 458 & 818 & 1276 \\
\hline $\begin{array}{l}\text { Transportation and } \\
\text { storage }\end{array}$ & $c 22$ & 1182 & 410 & 1592 & 613 & 974 & 1586 \\
\hline $\begin{array}{l}\text { Accommodation and } \\
\text { food services }\end{array}$ & $\mathrm{c} 23$ & 570 & 20 & 590 & 1599 & 511 & 2110 \\
\hline $\begin{array}{l}\text { Telecommunications } \\
\text { and other informa- } \\
\text { tion services }\end{array}$ & $c 24$ & 1264 & 175 & 1439 & 89 & 120 & 209 \\
\hline $\begin{array}{l}\text { Financial and insur- } \\
\text { ance activities }\end{array}$ & $\mathrm{c} 25$ & 2472 & 185 & 2656 & 63 & 87 & 150 \\
\hline Real estate activities & $c 26$ & 1104 & 164 & 1268 & 42 & 45 & 87 \\
\hline
\end{tabular}


Table 6 (continued)

\begin{tabular}{|c|c|c|c|c|c|c|c|}
\hline \multirow[t]{2}{*}{ Bogota industries } & \multirow[t]{2}{*}{ Code } & \multicolumn{3}{|c|}{ Value added in exports } & \multicolumn{3}{|c|}{ Value added in imports } \\
\hline & & Rest of Colombia & World & Total VAiX & Rest of Colombia & World & Total VAiM \\
\hline $\begin{array}{l}\text { Other business sec- } \\
\text { tor services }\end{array}$ & $c 27$ & 6660 & 1019 & 7679 & 18 & 24 & 42 \\
\hline $\begin{array}{l}\text { Public admin. and } \\
\text { defence; compul- } \\
\text { sory social security }\end{array}$ & $\mathrm{c} 28$ & - & - & - & 544 & 644 & 1188 \\
\hline Education & $\mathrm{c} 29$ & 2 & 0 & 2 & 63 & 102 & 165 \\
\hline $\begin{array}{l}\text { Human health and } \\
\text { social work }\end{array}$ & $\mathrm{c} 30$ & 322 & 5 & 328 & 160 & 751 & 910 \\
\hline $\begin{array}{l}\text { Arts, entertainment, } \\
\text { recreation and } \\
\text { other services }\end{array}$ & c31 & 407 & 53 & 460 & 56 & 138 & 194 \\
\hline $\begin{array}{l}\text { Private households } \\
\text { with employed } \\
\text { persons }\end{array}$ & c32 & - & - & - & - & - & - \\
\hline Total & & 22,641 & 3298 & 25,939 & 11,593 & 19,904 & 31,496 \\
\hline
\end{tabular}

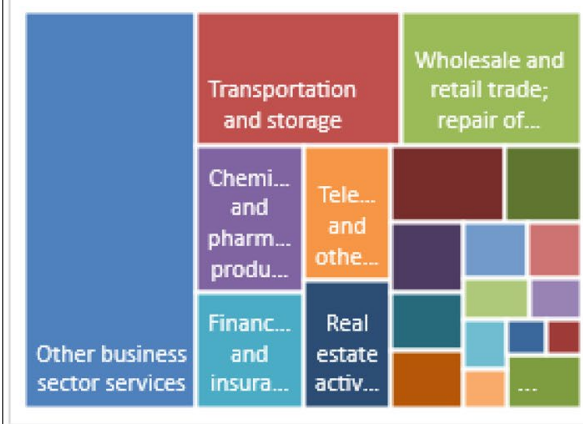

(a) Value added in exports

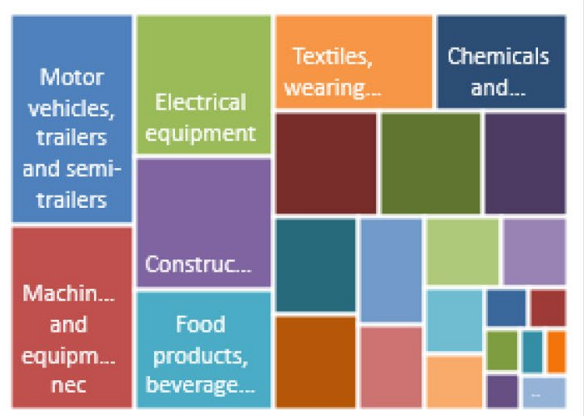

(b) Value added in imports

Fig. 5 Value added in international trade, Bogota industries, 2012

to conclude that there are no clear correspondences between sectors that are at the same time competitive (measured by their ability to generate value added in exports) and sectors that require a large amount of imports. In other words, contrary to what it is usually seen in sectors integrated to global value chains, Bogota's industries do not "import to export".

To deepen the analysis, let us now present the above information expressed in relative terms. We ask which is the amount of foreign value added that each sector imports or exports compared to the total value added generated. This is shown in Table 7. For example, foreign demand accounts for $33.4 \%$ of the total value added generated in the Motor vehicles industry of Bogota; or also, the value added generated by the Computer industry of Bogota is $99.9 \%$ foreign value added. In this way, we identify the industries that are more integrated to the global economy.

The information in this table permits to say, first, that there is a large difference in terms of participation of foreign value added in exports and in imports, consistent with the relatively closed economy of Bogotá. Second, even that there are some sectors that appear in both top ten lists (motor vehicles, rubber and plastics, chemical and 
Table 7 Bogota top 10 industries according to their foreign share in value added

\begin{tabular}{|c|c|c|c|}
\hline \multicolumn{2}{|l|}{ Value added in exports } & \multicolumn{2}{|l|}{ Value added in imports } \\
\hline Bogota sector & $\%$ Foreign & Bogota sector & $\%$ Foreign \\
\hline $\begin{array}{l}\text { Motor vehicles, trailers and semi- } \\
\text { trailers }\end{array}$ & 33.4 & $\begin{array}{l}\text { Computer, electronic and optical } \\
\text { products }\end{array}$ & 99.9 \\
\hline Rubber and plastic products & 14.3 & Other transport equipment & 99.9 \\
\hline Paper products and printing & 13.8 & Electrical equipment & 99.0 \\
\hline $\begin{array}{l}\text { Chemicals and pharmaceutical } \\
\text { products }\end{array}$ & 13.6 & Machinery and equipment, nec & 94.2 \\
\hline Basic metals & 12.5 & $\begin{array}{l}\text { Motor vehicles, trailers and semi- } \\
\text { trailers }\end{array}$ & 91.4 \\
\hline $\begin{array}{l}\text { Textiles, wearing apparel, leather } \\
\text { and related products }\end{array}$ & 11.8 & $\begin{array}{l}\text { Chemicals and pharmaceutical } \\
\text { products }\end{array}$ & 90.7 \\
\hline Fabricated metal products & 11.8 & Fabricated metal products & 71.9 \\
\hline Transportation and storage & 10.1 & Rubber and plastic products & 69.2 \\
\hline Other transport equipment & 9.8 & $\begin{array}{l}\text { Textiles, wearing apparel, leather } \\
\text { and related products }\end{array}$ & 60.9 \\
\hline Agriculture, forestry and fishing & 8.2 & $\begin{array}{l}\text { Wood and products of wood } \\
\text { and cork }\end{array}$ & 40.5 \\
\hline
\end{tabular}

pharmaceutical, textiles, fabricated metal products, other transport equipment), the low records of foreign value added in exports implies those sectors are poorly integrated to the international economy. In other terms, the city of Bogota needs imports to produce goods and services that are ultimately consumed in its own domestic market.

\section{Conclusions}

Endowed with the input-output table for the city of Bogota and the well-known OECD's ICIO table, we have shown the process of nesting the former into the latter comprehensively. We consider the incorporation of more detailed geographical analyses is a necessary step to a better understanding of globalization impacts at the city scale. Moreover, in a world increasingly characterized by the urbanization of economic activity and social relationships, having such details is a 'must' in order to propose better policies and conduct higher quality assessment analyses.

In the particular case we have addressed, we have benefitted from the fact that Bogota's IOT has a broader disaggregation than ICIO's, which undoubtedly facilitated our elaboration of sectoral correspondences between both tables. We have faced with diverse issues concerning data availability (e.g., lack of an updated table for Bogota) and required assumptions (to decide, for example, how to split sectorial aggregates into their intermediate and final components). However, we are confident that the result of our approach has yielded a robust representation of the city of Bogota in the international context given by the ICIO table.

We consider this article can inspire similar analyses for other cities in the world, in particular in Latin America's Mexico City and Sao Paulo or even Buenos Aires, Santiago and Lima. The countries these cities belong to are called to have an increasing role in the near future, which, together with the abovementioned urbanization process, invites to have a better understanding. Despite being integrated into global value chains only in their initial stages, these countries and cities have an essential stake in terms of 
Sustainable Development Goals given their natural resource endowment and food supply potential for the entire globe. Having tools such as input-output analysis to assess the environmental impacts and footprints (in terms of water use, emissions, waste and the like) of these global phenomena at city levels is an improvement concerning the more available aggregated, national-level approach.

Authors' contributions

All authors contributed to develop the methodology behind the nesting process. FM, MO, EG, JZ contributed to the redaction of distinct sections of the main manuscript. MAC contributed to the redaction and revision of Section 3. FM developed the MatLab code. All authors read and approved the final manuscript.

Funding

This work was supported by Ministerio de Economía y Competitividad of Spain (ECO2016-78938-R and BES-2017079618) and by the University of Castilla-La Mancha (UCLM).

Availability of data and materials

The original input-output tables used during the current study are available at http://www.oecd.org/sti/ind/inter-count ry-input-output-tables.htm and http://www.shd.gov.co/shd/matriz-eco-pub.

Competing interests

The authors declare that they have no competing interests.

Author details

${ }^{1}$ Global Energy and Environmental Economics Analysis Research Group, Faculty of Economics and Business, University of Castilla-La Mancha, Albacete, Spain. ${ }^{2}$ Faculty of Business, Finance and Economics, Ean University, Bogota, Colombia.

\section{Appendix: Multiregional input-output framework}

Current development of the multiregional input-output (MRIO) databases has favored the generalization of its implementation in multiple economic and environmental applications (López et al. 2017). The disaggregation level, in terms of both intermediate and final goods and services that the different available MRIO models feature, allows for better identification of global production chains (Tukker and Dietzenbacher 2013). The success of the MRIO models is based on the traceability of current international fragmentation of production processes among industries between different countries. In a MRIO table, the exports of a given sector of a country are the imports of the same or another sector in another country. The detailed direct and indirect linkages derived from that inter industrial relationships have provided institutions, organizations, governments, and countries with a significant amount of useful information to develop different environmental applications (López et al. 2017).

The MRIO table scheme is shown in Fig. 6, which represent a table with two countries and two sectors per country. By columns, in the intermediate goods block, we can differentiate between domestic and imported intermediate inputs. Note that intermediate inputs of region 1 from region 2 are equal to intermediate exports from region 2 to region 1 . In the first column of the final demand block, in turn, we can find the domestically supplied final demand of region 1 and the imported final demand of region 1 from region 2 (which is equal to the exports of final goods from region 2 to region 1 ). The value-added block provides information about the income generation by region and by industry in the production process. The sum-up by rows has to be equal to the sum-up by columns (Peters et al. 2011; López et al. 2017). 
The MRIO model can be easily explained by starting from the fundamental equation of Leontief's quantity model, an $n$ linear equations system with $\mathrm{n}$ variables, shown in Eq. 14:

$$
x=(I-A)^{-1} y,
$$

where $x$ is the total output, $A$ is the technical coefficients matrix, $(I-A)^{-1}$ is the inverse matrix of Leontief and $y$ is the final demand vector.

Taking into account the production of several regions in a multiregional context (López et al. 2017), the MRIO can be expressed as:

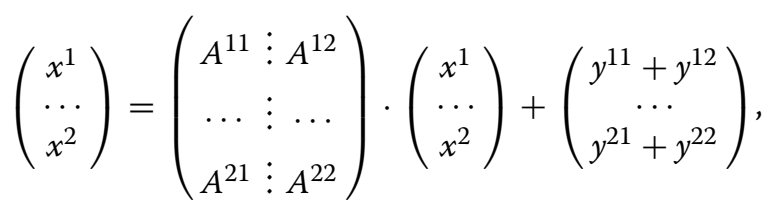

where $x^{r}$ is the output vector of each of the regions. $A^{r r}$ is the domestic technical coefficients matrix of region $r$, and $A^{r s}$ is region $r$ technical coefficients matrix of imported intermediate goods from region $s$. Finally, $y^{r r}$ stands for the domestic final demand vector of region $r$, while $y^{r s}$ are the vectors of final demand of region $r$ from region $s$ (i.e., region $s$ exports of final goods and services to region $r$.)

Following Peters (2008), expression 15 can be rewritten for two different industries in two different regions as follows:

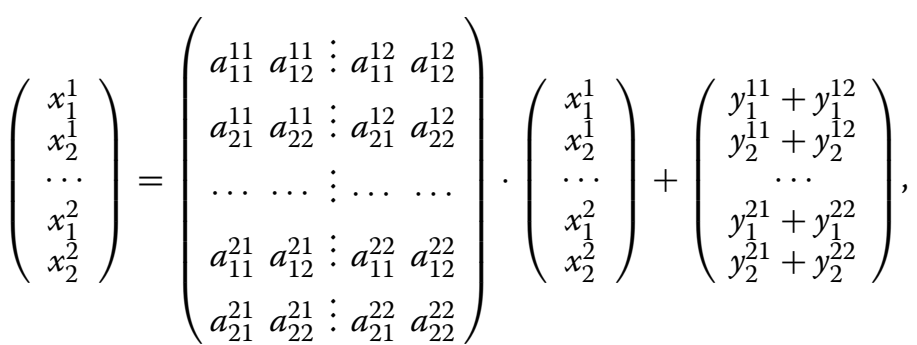

where $x_{j}^{r}$ denotes the output of industry $j$ in each of the regions $r$; $a_{i j}^{r r}$ is an element of the domestic technical coefficients matrix for each region $r$ and the $i$ and $j$ industries; and $a_{i j}^{s r}$ is the analog measure but involving two different regions $s$ and $r$. Each of the technical coefficient represents a share of the output of the industry in a region $r$ or $s$, bought as an intermediate input by the industry $j$ in a $r$ or $s$ region. The final demand components $y_{i}^{r r}$ and $y_{i}^{r s}$ are referred to the domestic final demand of a region $r$ of $i$ goods, and the imported final demand of region $r$ from region $s$ of $i$ goods, respectively.

The previous expression can be solved in a multiplicative way using the concept of the inverse matrix of Leontief, where $L=(I-A)^{-1}$ (López et al. 2017). The information provided by $L$ is the same as in a single region model, that is total (direct and indirect) requirements to supply the production of an additional unit of final demand, but now including domestic and imported requirements. The resulting expression would be: 


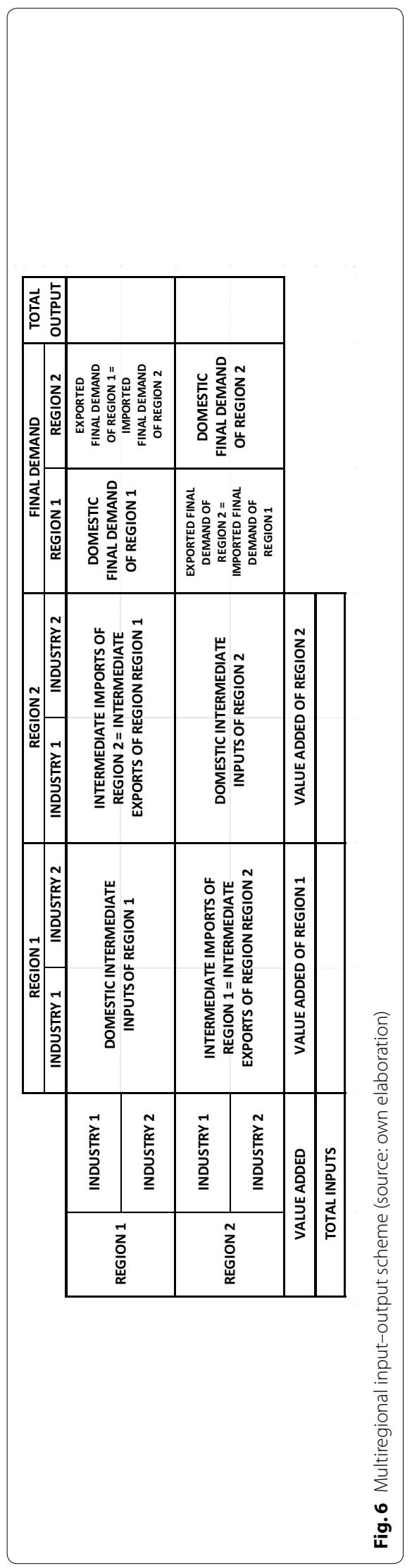




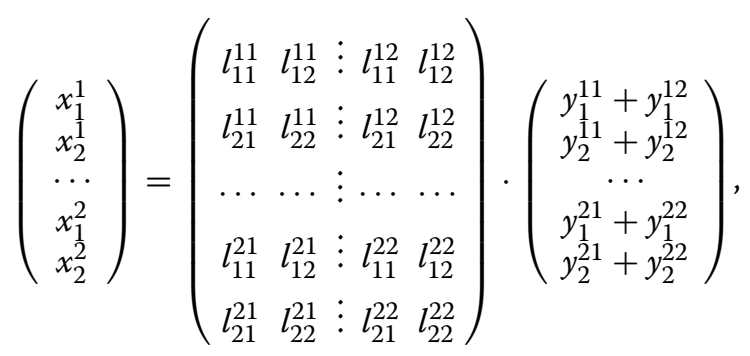

where $l$ elements represent the components of the domestic $\left(l^{r r}\right)$ or imported $\left(l^{r s}\right)$ output multipliers of the Leontief inverse matrix. The output multiplier shows the difference between the initial and the total effect of an exogenous impact in an industry. We can define the total effect as the direct and indirect (those generated in other industries) impact generated in the output of an industry $j$ to supply a unit increase of the final demand in the industry $i$ (Miller and Blair 2009).

The participation of Bogota and Colombia in the global value chains, developed in the case study of this paper, is going to be showed on next expression:

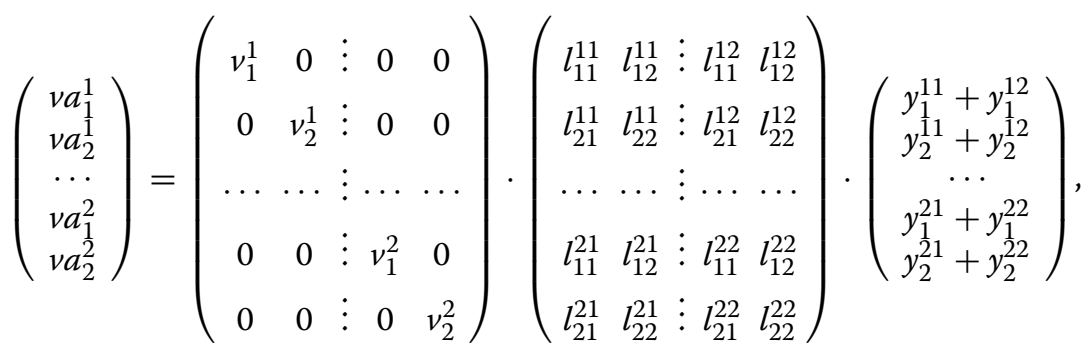

where $v_{j}^{r}$ is value added coefficients vector for each region $r$ and $j$ industries, and $\mathrm{va}_{1}^{1}$, denotes the value added of industry $j$ in each of the regions $r$.

Received: 18 July 2019 Revised: 21 November 2019 Accepted: 18 January 2020

Published online: 03 February 2020

\section{References}

Athanassiadis A, Christis M, Bouillard P, Vercalsteren A, Crawford RH, Khan AZ (2018) Comparing a territorial-based and a consumption-based approach to assess the local and global environmental performance of cities. J Clean Prod 173:112-123. https://doi.org/10.1016/j.jclepro.2016.10.068

Banacloche S, Cadarso MÁ, Monsalve F (2020) Implications of measuring value added in exports with a regional inputoutput table. A case of study in South America. Struct Change Econ Dyn 52:130-140. https://doi.org/10.1016/j.strue co.2019.08.003

Boero R, Edwards BK, Rivera MK (2018) Regional input-output tables and trade flows: an integrated and interregional non-survey approach. Reg Stud 52(2):225-238. https://doi.org/10.1080/00343404.2017.1286009

Chen G, Wiedmann T, Wang Y, Hadjikakou M (2016) Transnational city carbon footprint networks-Exploring carbon links between Australian and Chinese cities. Appl Energy 184:1082-1092. https://doi.org/10.1016/j.apenergy.2016.08.053

Dane (2009) Methodology. International Standard Industrial Classification of All Economic Activities. vol 47

Dane (2019) Microdatos de Comercio Internacional. https://sitios.dane.gov.co/anda-index/

Gilles E (2018) Cadenas globales de valor, empleo y servicios: evidencia para algunos países latinoamericanos. Tec Empresarial 12:7-18

Hasegawa R, Kagawa S, Tsukui M (2015) Carbon footprint analysis through constructing a multi-region input-output table: a case study of Japan. J Econ Struct 4(1):5. https://doi.org/10.1186/s40008-015-0015-6

Junius T, Oosterhaven J (2003) The solution of updating or regionalizing a matrix with both positive and negative entries. Econ Syst Res 15(1):87-96. https://doi.org/10.1080/0953531032000056954

Lenzen M, Moran D, Kanemoto K, Geschke A (2013) Building Eora: a global multi-region input-output database at high country and sector resolution. Econ Syst Res 25(1):20-49. https://doi.org/10.1080/09535314.2013.769938 
López LA, Zafrilla J, Álvarez S (2017) Volumen 6: La huella de carbono y el análisis input-output, vol 6. Huella de Carbono, Asociación Española de Normalización y Certificación (AENOR)

Malik A, McBain D, Wiedmann TO, Lenzen M, Murray J (2018) Advancements in input-output models and indicators for consumption-based accounting. J Ind Ecol. https://doi.org/10.1111/jiec.12771

Meng B, Yamano N (2017) Compilation of a regionally extended inter-country input-output table and its application to global value chain analyses. J Econ Struct 6(1):23. https://doi.org/10.1186/s40008-017-0081-z

Meng J, Liu J, Guo S, Huang Y, Tao S (2016) The impact of domestic and foreign trade on energy-related PM emissions in Beijing. Appl Energy 184:853-862. https://doi.org/10.1016/j.apenergy.2015.09.082

Miller RE, Blair PD (2009) Input-output analysis: foundations and extensions, 2nd edn. Cambridge University Press, Cambridge

OCDE (2018) Inter-country input-output (ICIO) tables. http://www.oecd.org/sti/ind/inter-country-input-output-table s.htm

Peters GP (2008) From production-based to consumption-based national emission inventories. Ecol Econ 65(1):13-23. https://doi.org/10.1016/j.ecolecon.2007.10.014

Peters GP, Andrew R, Lennox J (2011) Constructing an environmentally-extended multi-regional input-output table using the GTAP databse. Econ Syst Res 23(2):131-152. https://doi.org/10.1080/09535314.2011.563234

Secretaria de Hacienda Distrital (2015) Input-output table for the year 2012. http://www.shd.gov.co/shd/matriz-eco-pub

Sun Z, Tukker A, Behrens P (2019) Going global to local: connecting top-down accounting and local impacts, a methodological review of spatially explicit input-output approaches. Environ Sci Technol 53(3):1048-1062. https://doi. org/10.1021/acs.est.8b03148

Temurshoev U, Miller RE, Bouwmeester MC (2013) A note on the gras method. Econ Syst Res 25(3):361-367. https://doi. org/10.1080/09535314.2012.746645

Thissen M, Lankhuizen M, van Oort F, Los B, Diodato D (2018) EUREGIO: The construction of a global IO DATABASE with regional detail for Europe for 2000-2010. Tinbergen Institute Discussion Paper TI 2018-084/NI

Torres D, Gilles E (2013) Estructura tecnológica de las exportaciones industriales en América Latina (1990-2010). ADminister. pp 95-111

Tsukui M, Kagawa S, Kondo Y (2015) Measuring the waste footprint of cities in Japan: an interregional waste input-output analysis. J Econ Struct 4(1):18. https://doi.org/10.1186/s40008-015-0027-2

Tukker A, Dietzenbacher E (2013) Global multiregional input-output frameworks: an introduction and outlook. Econ Syst Res 25(1):1-19. https://doi.org/10.1080/09535314.2012.761179

United Nations (2008) International Standard Industrial Classification of All Economic Activities. Revision 4. Statistical Papers. New York

Wang Y, Geschke A, Lenzen M (2015) Constructing a time series of nested multiregion input-output tables. Int Reg Sci Rev 40(5):476-499. https://doi.org/10.1177/0160017615603596

Weber CL, Peters GP, Guan D, Hubacek K (2008) The contribution of Chinese exports to climate change. Energy Policy 36(9):3572-3577. https://doi.org/10.1016/j.enpol.2008.06.009

Wiedmann T, Barrett J (2013) Policy-relevant applications of Environmentally extended MRIO databases_experiences from the UK. Economic Systems Research 25:143-156

Wiedmann T, Lenzen M (2018) Environmental and social footprints of international trade. Nat Geosci 11(5):314-321. https ://doi.org/10.1038/s41561-018-0113-9

Wiedmann TO, Chen G, Barrett J (2016) The Concept of city carbon maps: a case study of Melbourne, Australia. J Ind Ecol 20(4):676-691. https://doi.org/10.1111/jiec.12346

Zheng H, Meng J, Mi Z, Song M, Shan Y, Ou J, Guan D (2019) Linking city-level input-output table to urban energy footprint: construction framework and application. J Ind Ecol. https://doi.org/10.1111/jiec.12835

\section{Publisher's Note}

Springer Nature remains neutral with regard to jurisdictional claims in published maps and institutional affiliations.

\section{Submit your manuscript to a SpringerOpen ${ }^{\circ}$ journal and benefit from:}

- Convenient online submission

- Rigorous peer review

- Open access: articles freely available online

High visibility within the field

Retaining the copyright to your article

Submit your next manuscript at $\boldsymbol{s p r i n g e r o p e n . c o m ~}$ 